Digital Press Social Sciences and Humanities

Utilization of Social Media in Young Families as Media Parenting in the Millennial Era

Ellyn Sugeng Desyanty

Proceeding of The Non-Formal Education International Conference 2020

Alim Harun Pamungkas, Jamaris, Solfema (eds) 


\title{
Utilization of Social Media in Young Families as Media Parenting in the Millennial Era
}

\author{
Ellyn Sugeng Desyanty \\ Department of Non-Formal Education Universitas Negeri Malang, Malang, Indonesia \\ e-mail: ellyn.sugeng.fip@um.ac.id
}

\begin{abstract}
Parenting activities in young families at this time have experienced a very fast development that is from activities that are offline to online. This is due to the development of information technology that presents a variety of new information can be spread very quickly. Social media was chosen as a source of learning for young families in providing learning experiences, especially about child development and answers to various problems that arise in the process of forming a family. the findings show that social media which later became a discussion forum in cyberspace has been considered as a more credible media for discussion, exchanging experiences. Social media has become one of the most popular sources of learning among young families.
\end{abstract}

\section{Keywords}

social media, parenting, young families

\section{Introduction}

The development of rapidly developing information technology has influenced the shift in the way people obtain information. Social media has become the most popular source of choice for finding information quickly and easily. The use of smartphones in Indonesia is more widely used for social media, communication, accessing the internet and obtaining all information for users. The APJII survey (2018) said internet users in Indonesia had increased by about 8\% to 143.26 million, equivalent to $54.68 \%$ of the Indonesian population.

The orientation of young families in looking for sources of information has experienced a shift that in the past the main source of information for young families was their parents who were considered to have more experience in childcare. Access to parenting information which was previously only in the offline sphere has now shifted towards online. Exchange of information is no longer limited by space and time. Young people are more interested in finding and sharing various information through social media, through social media one can communicate with others without having to meet face to face or meet in person. It is this ease that causes social media to become increasingly popular in choosing fast and inexpensive learning resources, which in this study are learning resources in parenting.

Research published in 2014 by Crowdtap, Ipsos MediaCT, and The Wall Street Journal shows that the amount of time spent by users to access the internet and social media reaches 6 hours 46 minutes per day, exceeding the activity to access traditional media (Nasrullah, 2015). From this statement it can be seen that social media has become dominant in the community so that it does not become new when everyone, especially young family couples rely on the internet and social media in obtaining the latest information they need

Parenting is a pattern of interaction between children and parents that not only includes the fulfillment of physical needs (eating, drinking, clothing) and psychological needs (affection or feeling) but also the norms prevailing in society so that children can live in harmony with their environment (Gunarsa, 2002). Parenting begins when the child is in the womb until a person has met the criteria as an adult human.

Parenting is all things that should be done by parents or caregivers in carrying out tasks and responsibilities towards the development of children (Hidayati, 2001). The task of parents develop not only to meet physical needs but also to meet other needs such as material needs, emotional and psychological needs of children, as well as providing access to educational facilities. For every family, especially young people, this is done with many businesses that require the assistance of others. The 
results of preliminary observations found that every couple in a young family does not specifically prepare themselves to become parents at the beginning of forming a family, so everything that is done when the presence of new members (children) in their lives requires support from those around him to support what is they do.

The presence of new members is a challenge for young families, they are faced with various obligations relating to child growth and development. They must be able to care for and educate children to become new individuals who will become part of social society. The role of parenthood is not easy, especially for young families who still have limited experience. The limitation of information on being a parent is what makes parents from young families meet the needs of information not obtained through offline learning spaces. Social media as an online learning space is considered capable of providing information needed to meet the information needs related to parenting.

The young families in this study were husband and wife couples who had been married for less than 10 years and had at least one child in their care. This study aims to determine the motives for using social media as a learning resource for parenting among young families with at least one child living in one house.

\section{Methods}

This research uses a qualitative research method with a phenomenological study approach. This research begins by examining the focus of research to be studied. Phenomenology seeks to understand how a person gives meaning to an experience that is carried out (Kuswarno, 2009). The experience of young families in obtaining parenting information can be known directly based on the experiences of the informants.

The data obtained from this study were obtained from the in-depth interview process and focus group discussion (FGD). Data collection is also carried out by the process of examining a number of sources relating to the focus of research.

The data analysis process is carried out simultaneously by classifying data, sorting and separating data, and looking for relationships between one data with another data. This is done so that the data can be presented in a sequential and orderly manner. The data linkages are used to draw conclusions from the data found

\section{Result and Discussion}

\subsection{Use of Social Media in Young Families}

The results of the study mentioned that of 15 married couples who have been married for less than 10 years have used social media as a source of learning parenting. Social media that are used are diverse, including WhatsApp, Instagram, and Facebook, which in this study are then referred to as media partners parenting. Social media is a source of learning and self-actualization in parenting activities. The level of use of social media in Indonesia is relatively high, as evidenced by the APJII survey, which states that internet users in Indonesia have increased about 8\% to 143.26 million people, equivalent to $54.68 \%$ of Indonesia's population (APJII, 2018).

The number of users of social media is very high both in the activity of conversation or reporting on social media makes social media considered very effective in disseminating information and discussions. Social media provides space especially for people who do not have the ability to discuss in public spaces. Social media provides facilities for everyone to express their opinions and look for information needed online which will then influence the formation of activities in social behavior in the offline world.

This study found that some young families use social media that makes it easy for them to interact, namely: WhatsApp, Facebook, and Instagram. WhatsApp ranks first chosen by research informants because it is considered very easy to use and meets their needs in disseminating and obtaining information. The results of this study indicate that the fulfillment of information needs is needed in a very fast time. Social media will be left by the user if it is felt unable to meet the information needs in a short time. Information needs are requests for information that is a manifestation of a sense of lack in oneself (Afrilia, 2017). 
Social media has a function and benefit in facilitating young families to interact and communicate with many people in various fields, especially in parenting. The results showed that young families use social media as a means to exchange experiences, information, and discussions about various problems encountered in the hope of getting responses from others. Issues that are often discussed in social media about how to care for children, overcome child problems, as well as information about products that are safe for children.

Young families use social media to interact with other people they have never even met in the real world to obtain and provide new information in matters relating to parenting through discussion forums and readings in the form of short articles. Research findings suggest that in social media not only are discussion forums and articles about the parenting they are looking for, but also often information in the form of videos or images is also very popular because they are more easily accepted and provide convenience in absorbing new information,

The research findings obtained information that busy outside the home for young families causes them to feel they do not have enough time to accompany children at home. But these problems do not make them want to lose important moments in the development of their children. So that social media is needed to always know the development of children while not with them and in the care of others at home. The young families who were respondents in this study had the hope of always monitoring the condition of their children when they were not with them, being able to present them not only physically when they met their children but also when they were not close to their children.

Research findings obtained through in-depth interviews and FGDs gained several reasons why young families use social media in seeking parenting information, including: (1) social media is believed to be able to provide the latest information about parenting; (2) allows each person to interact with other people even though they do not actually meet; (3) makes it easy for working couples to discuss each other's experiences without taking time specifically; (4) more accessible and economical; (5) the use of language in social media that is easily understood by all people from various backgrounds.

\subsection{Motives for Using Social Media in Young Families}

The following is an explanation of the motives of young families in using social media, namely:

\subsubsection{Cognitive Motives}

Respondents think that social media helps in finding and sending information sources. Information obtained through social media varies, often the information obtained and sent about how to care for children, overcome child problems, as well as information about products that are safe for children. Social media has a big role in changing information discovery behavior which is also supported by the capabilities of the information provider. Social media provides information when a person starts surfing (surfing) from the site he starts (then) which is then followed by a link to the source of information that is related (chaining); observing selected sites (browsing); mark useful sources for other time interests (differentiating); send e-mail to the available address to keep abreast of the latest information (monitoring); and looking for sources or sites that contain information from specific topics (extracting) (Choo, Detlor, \& Turnbull, 2000).

\subsubsection{Personal Identity Motives}

Research findings show that social media activities that are most commonly used are updating status and commenting on other people's posts. This shows that some couples in young families who have a motive for their existence need to be recognized by others through their presence in cyberspace. According to the informants in this research, they are not only considered important to be recognized by others but also important to their children. The results of the study stated that they as parents hope that they can always be with their children even though not only physically but also always communicate when children are not with them at the same time and place.

Motives are impulses, desires, desires, and other driving forces that come from within someone to do something (Sanjaya, 2006). The results showed that the motives underlying one's actions in using social media as a source of learning parenting are influenced by the need for meaning to his concept. The perception of an object of perception that concerns oneself will take place constantly (Kuswarno, 2009). The assessment in question can involve cognitive knowledge and everything related to feelings. The concept of self can be separated into two main things, namely self image and self esteem (Rakhmat, 2005). Self image is related to individual cognitive factors and self esteem is related to individual affective 
factors. The motives that emerge in this study are cognitive motives that are rational in relation to the logical values possessed by informants, namely when informants state that they use social media as a source of learning in meeting their needs about parenting. Informants also have other motives which are emotional motives where informants need recognition of their existence in cyberspace.

\section{Conclusion}

The self-concept of young couples is demonstrated through the use of social media in meeting their needs for sources of information about parenting. Social media chosen as a source of learning among young families is social media that is considered easy to use and access to information. The use of social media in young families has cognitive motives and personal identity motives. Furthermore, parents are expected to be able to use social media as a source of information in fulfilling their needs wisely.

\section{References}

Afrilia, A. M. (2017). Penggunaan New Media di Kalangan Ibu Muda sebagai Media Parenting Masa Kini. Jurnal Komunikasi Dan Kajian Media, 1(1), 31-42.

APJII. (2018). Potret Zaman Now: Pengguna \& Perilaku Internet Indonesia (23rd ed.). Jakarta.

Choo, C. W., Detlor, B., \& Turnbull, D. (2000). Information seeking on the Web: An integrated model of browsing and searching. First Monday, 5(2). https://doi.org/10.5210/fm.v5i2.729

Gunarsa, S. D. (2002). Psikologi Perkembangan Anak dan Remaja. Jakarta: PT. Gunung Mulia.

Hidayati, Z. (2001). Anak Saya Tidak Nakal. Yogyakarta: PT. Bintang Pustaka.

Kuswarno, E. (2009). Fenomenologi: Konsepsi, Pedoman, dan Contoh Penelitian. Bandung: Widya Padjajaran.

Nasrullah, R. (2015). Media Sosial: Persepektif Komunikasi, Budaya, dan Sosioteknologi. Bandung: Simbiosa Rekatama Media.

Rakhmat, J. (2005). Psikologi Komunikasi. Bandung: Remaja Rosdakarya.

Sanjaya, W. (2006). Strategi Pembelajaran Berorientasi Standar Proses Pendidikan. Bandung: Kencana. 